\title{
An overview of Suctorian ciliates (Ciliophora, Suctorea) as epibionts of halacarid mites (Acari, Halacaridae)
}

\author{
IGOR DOVGAL ${ }^{1}$, TAPAS CHATTERJEE ${ }^{2} \&$ BABAN INGOLE $^{3}$ \\ ${ }^{1}$ Schmalhausen Institute of Zoology, B. Khmelnitsky str., 15, 01601, Kiev, Ukraine. E-mail: dovgal@izan.kiev.ua \\ ${ }^{2}$ Department of Biology, Indian School of Learning, I.S.M. Annexe, P.O. - I.S.M., Dhanbad-826004, Jharkhand, India. \\ E-mail:drtchatterjee@yahoo.co.in \\ ${ }^{3}$ Biological Oceanography Division, National Institute of Oceanography, Dona Paula, Goa-403004, India. E-mail: baban@nio.org
}

\begin{abstract}
Scant information is available regarding the prevalence and distribution of suctorian ciliates on halacarid mites. However, using this limited information and data from our laboratory on the systematics, biology, ecology and distribution of suctorian ciliates that are epibionts of halacarid mites, we redescribed four suctorian species: Limnoricus ceter (Jankowski), Praethecacineta halacari (Schulz), Thecacineta calix (Schroder) and Acineta sulcata Dons. We also recognized Lissacineta allgeni Jankowski and Thecacineta allgeni (Jankowski) as synonyms of Praethecacineta halacari (Schluz), and Thecacineta laophontis Jankowski and Paracineta moebiusi Kahl as synonyms of Thecacineta calix (Schroder). Many suctorians have been reported, but not properly identified in the halacarid literature. So, we have attempted to identify those suctorians to species level. Lastly, the interactions between the suctorians and their hosts are also discussed and Praethecacineta halacari is also reported for the first time from the Indian coast.
\end{abstract}

Key words: Ciliophora, Suctorea, Halacaridae, epibionts

\section{Introduction}

Representatives of several groups of freshwater and marine aquatic mites have been identified as hosts of suctorian ciliates (Suctorea) (Precht 1935; Matthes 1956; Matthes \& Stiebler 1970; Matthes et al. 1988; Dovgal 1996; Gelmboldt \& Dovgal 2005; Dovgal \& Pesic 2007). There are extensive literature, along with figures and photomicrographs, on the halacarid mites, on which the suctorians occur (Abé 1997; Grimaldi 1965; Bartsch 1989, 1994, 1998, 2001, 2003; Chatterjee et al. 2004, 2006; Pepato \& Tiago 2005). However, very little information is available regarding the distribution and prevalence of suctorian ciliates on these mites. Moreover, several species have been insufficiently described and documented in the old literature, and many nomenclatural problems were not addressed. In some cases, the suctorian species were not identified to species or even genus level. As a result, we have tried to identify some species of suctorians from figures and photomicrographs in the halacarid literature (Bartsch 1989, 1998, 2001, 2003; Abé 1997; Bartsch \& Panesar 2000; Pepato \& Tiago 2005). In addition, several suctorian-infested halacarid mites were recently collected from Goa (West coast of India, Arabian Sea) for examination. This paper presents an analysis of pertinent literature and data on the systematics, biology, ecology and distribution of suctorian epibionts of halacarid mites. 


\section{Material and methods}

Halacarid mites were collected from two rocky intertidal beaches of Goa; viz. Anjuna (Lat. 15 ${ }^{\circ} 34^{\prime}$ '58" N;

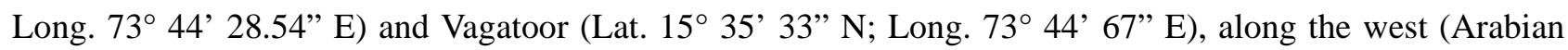
Sea) coast of India. Collections were made from the intertidal to subtidal zone in May 2007. In addition, samples that were collected from the sandy coast of Ukraine, along the Black Sea, between 2003-2004, were reexamined. Original identifications of the Black Sea suctorians from halacarids were published in Boshko and Dovgal (2004), and Gelmbolt and Dovgal (2005). In the present study, measurements were made using the computer program ScopePhoto 2.0 for processing of digital images. Permanent slides of infested halacarids were deposited in the collections of the Department of Fauna and Systematics of invertebrate animals of Schmalhausen Institute of Zoology, National Academy of Sciences, Ukraine.

\section{Results and discussion}

The systematic position (according to Dovgal's 2002 system), diagnoses, redescriptions and remarks on the nomenclature of suctorians from halacarid mites, along with their distribution and host preference are discussed below.

\section{Class Suctorea Claparède \& Lachmann}

\section{Subclass Exogenia Collin}

\section{Order Metacinetida Jankowski}

\section{Family Paracinetidae Jankowski}

\section{Limnoricus ceter Jankowski, 1981}

(Fig. 1-3)

Diagnosis: Marine commensal, loricate, suctorian ciliate with stalk delimited from posterior margin of lorica. Both lorica and cell body sharply flattened laterally. Top of lorica orbed. The apical aperture of lorica surrounded by collar-like borders. Stalk long, straight and somewhat enlarged near junction with lorica. Cell body attached to margin of lorica aperture. Macronucleus ellipsoidal, located medially. Contractile vacuole not observed. Specimens from halacarid mites have short and convoluted stalk. Lorica dimensions: 65-74 $\mu \mathrm{m}$ long x 36-44 $\mu \mathrm{m}$ wide. Stalk length up to $160 \mu \mathrm{m}$.

Distribution and host prevalence: Limnoricus ceter was described from marine isopods from the Sakhalin and Kunashyr Islands (Jankowski 1981). It was also found on halacarid mites from Barents Sea (Jankowski 1981). Since the specimens from halacarids differ from the individuals from isopods based upon the form of the stalk, Jankowski (1981) proposed that halacarid forms are possibly restricted to a particular/single species.

\section{Family Praethecacinetidae Dovgal}

Praethecacineta halacari (Schulz, 1933), charact. emend

(Fig. 4, 5, 9-11)

=Thecacineta halacari Schulz, 1933 
=Lissacineta allgeni Jankowski, 1981, syn. n.

$=$ Thecacineta allgeni $($ Jankowski, 1981), syn. n.

Diagnosis: Marine suctorians with stylotheca. Cell body, slightly, laterally flattened, entirely filling the lorica and attached to its posterior margin. Apical part of the body narrowed.
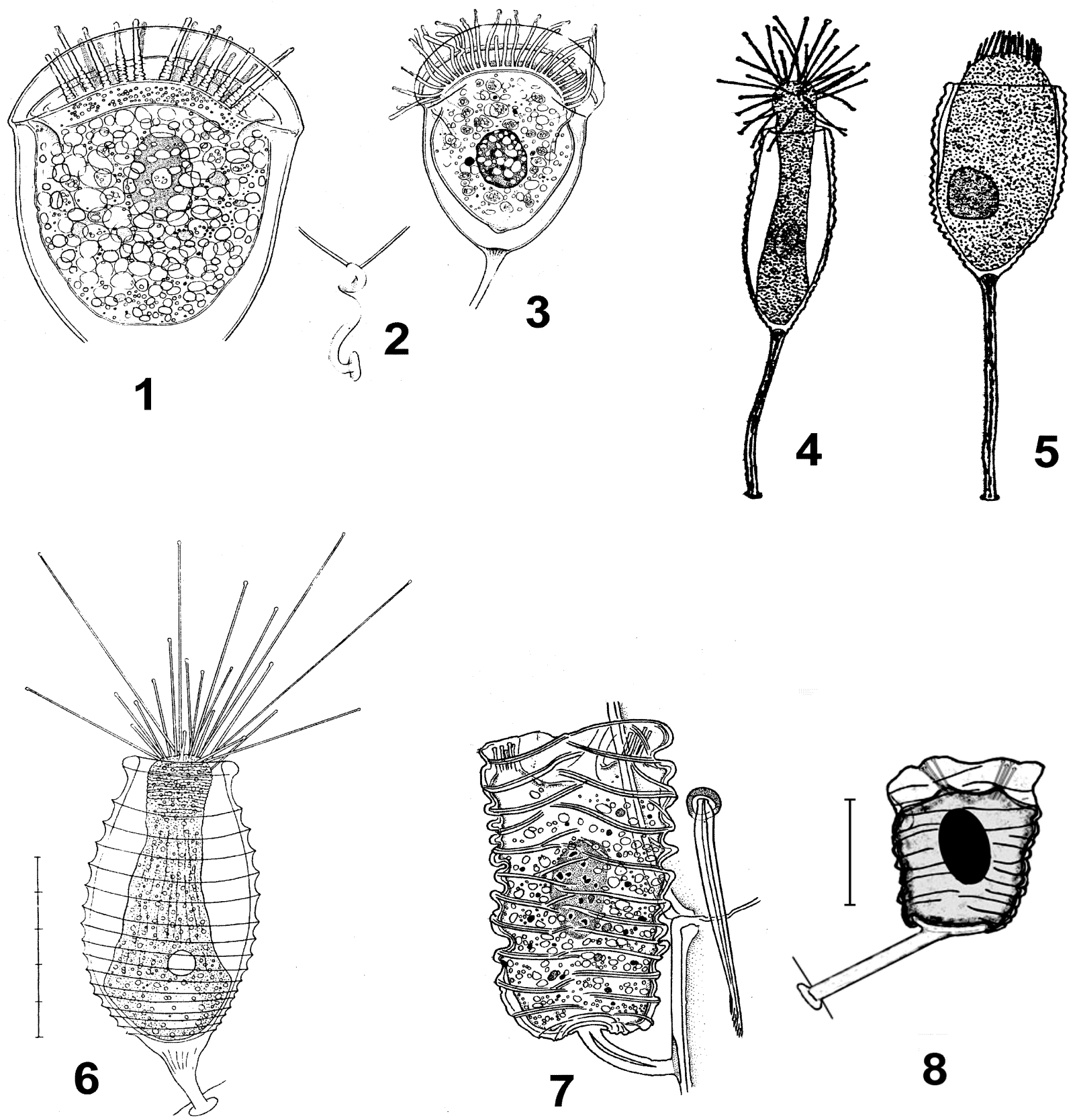

FIGSURES 1-2. Limnoricus ceter Jankowski, 1981 from halacarid mite (2—stalk) (after Jankowski 1981).

FIGURE 3. Limnoricus ceter from isopode crustacean (after Jankowski 1981).

FIGURES 4-5. Praethecacineta halacari (Schulz, 1933) (after Schulz 1933).

FIGURE 6. Thecacineta calix (Schroder, 1907) (after Matthes 1956). Scale bar $50 \mu \mathrm{m}$.

FIGURE 7. Acineta sulcata Dons, 1927 from Barents Sea halacarid mites (after Jankowski 1981).

FIGURE 8. Acineta sulcata Dons, 1927 from freshwater halacarid mite found in Unava river (orig.). Scale bar $10 \mu \mathrm{m}$.

Tentacles placed at upper cell surface. Macronucleus spherical, posteriorly located. Contractile vacuole single. Stylotheca smooth, without ribbing. Body dimensions: lorica length 31-38 $\mu \mathrm{m}(85-110 \mu \mathrm{m}$ after 
Schulz 1933), lorica width 18-21 $\mu \mathrm{m}$ (35-55 $\mu \mathrm{m}$ after Schulz 1933), stalk length 3-26 $\mu \mathrm{m}$ (50-110 $\mu \mathrm{m}$ after Schulz 1933). Reproduction by semi-circumvaginative exogemmic budding with formation of laterally placed ciliary swarmers (Fig. 10). Original measurements of Pra. halacari were made using specimens from Goa, India.

Remarks on the systematics and nomenclature: Pra. halacari was described from marine halacarid mites from interstitial sand (Schulz 1933) and classified with the genus Thecacineta Collin, 1909. However, except for Pra. halacari, formation of unciliated swarmers is characteristic for all species of the genus. It was for this reason that Matthes (1956) assigned Pra. halacari to the current genus Praethecacineta Matthes, 1956 and placed it together with the genus Thecacineta in a new family, Thecacinetidae. Finally, in the keys for identification of suctorians of Ukraine (Dovgal 1996), Praethecacineta was placed into the subclass Exogenia Collin, 1912 in the new family Praethecacinetidae Dovgal, 1996, based on the type of budding.

Jankowski (1981) noted that the species identified by Batisse (1965) as Pra. halacari was wrongly identified and proposed the new species name Lissacineta allgeni. The generic name was later synonymyzed by Dovgal (2002) with Thecacineta, and Lis. allgeni was transferred into the genus. However, the absence of lorica ribbing warranted new species erection by Jankowski (1981), while a smooth and slightly folded lorica is characteristic for Pra. halacari. Thus, Jankowski's species is considered a junior synonym of Pra. halacari.

Distribution and host prevalence: The species was previously observed near the Norwegian coast (Troms $\varnothing$ ) and in the Kiel Bay (Schulz 1933) on unidentified halacarids. Precht (1935) later identified Pra. halacari on Copidognathus spp in the latter locality. Rare instances of the species are also known from the Bulgarian coast of the Black Sea (Detcheva 1992).

Praethecacineta halacari was found on the legs and body surface (both ventrally and dorsally) of Copidognathus brachystomus Viets from the Black Sea near Karadag Natural Reserve (Kurortnoye, Crimea region, Ukraine; Boshko \& Dovgal 2004). It was also recorded in interstitial sand at Cape Martian Reserve near the village of Nikita in the Yalta region (Crimea), from an unidentified halacarid mite (Gelmboldt \& Dovgal 2005).

Among the suctorians observed by Bartsch $(1989,1998,2001,2003)$, we identified several individuals of Pra. halacari on the idiosomas of the following halacarid mites: Cop. brachystomus Viets (Bartsch 2001), Cop. magnipalpus (Police), and Caspihalacarus hyrcanus Viets (Bartsch 1998) from Black Sea soft sediment; Cas. hyrcanus from the Caspian Sea (Bartsch 1998); Cop. brifacius Bartsch from sandy deposits from the North Sea (Bartsch 1989); and on the idiosoma and gnathosoma of Cop. meridianus Bartsch off the coast of Western Australia (Bartsch 2003). Furthermore, from the figure in Pepato \& Tiago (2005), we have also identified Pra. halacari on the idiosoma of Cop. tupinamborum Pepato \& Tiago from the Atlantic coast of Brazil.

In the present study, we have also found Pra. halacari on Cop. arabicus Chatterjee \& Chang collected from Goa on the west coast of India (Arabian Sea) (Figs. 9-11). Seven of the 33 mites were infested by suctorians. We observed that Pra. halacari was found on Cop. arabicus, but not on species of the co-occurring genera Rhombognathus and Agauopsis. Furthermore, Pra. halacari is reported here for first time from India.

\section{Subclass Vermigenia Jankowski}

\section{Order Spelaeophryida Jankowski}

\section{Family Thecacinetidae Matthes}

Thecacineta calix (Schroder, 1907)

(Fig. 6, 12)

= Acineta calix Schroder, 1907

= Thecacineta desmodorae Schulz 
= Thecacineta subantarctica Allgen

= Thecacineta donsi Allgen

= Thecacineta paradesmodorae Allgen

= Thecacineta laophontis Jankowski, 1981, syn. n.

= Paracineta moebiusi Kahl, 1934, syn. n.

Diagnosis: Type species of the genus. Marine loricate, suctorian. Cell body entirely fills the lorica and attached to their bottom. Lorica totally ribbed transversely. Apical part of body protrudes beyond lorica aperture. Up to 30 clavate tentacles with length about $90 \mu \mathrm{m}$ arise from upper body surface. Macronucleus large, oviform, located at the bottom of the cell body. With large contractile vacuole placed in basal body part usually near macronucleus. Body dimensions: lorica high 73-113 $\mu \mathrm{m}$ (75-105 $\mu \mathrm{m}$ after Matthes 1956), width 25-28 $\mu \mathrm{m}$ (39-53 $\mu \mathrm{m}$ after Matthes 1956), body length 73-140 $\mu \mathrm{m}$, body width 16-21 $\mu \mathrm{m}$, diameter of lorica aperture (after Matthes 1956) 18-30 $\mu \mathrm{m}$, macronucleus dimensions 7-16 x 6-7 $\mu \mathrm{m}$, stalk length 9-39 $\mu \mathrm{m}$ (10-33 $\mu \mathrm{m}$ after Matthes 1956), stalk diameter 1.6-2 $\mu \mathrm{m}$. Reproduction by vermigemmy with formation of single larval stage (swarmer), devoid of ciliature and crawling over the substrate.

Remarks on the systematics and nomenclature: Thecacineta calix, a marine, loricate, suctorian ciliate with a single apical fascicle of tentacles, was described from marine nematodes (Schroder 1907). Subsequently, Collin (1909) combined all known species that had a similar morphology into the genus, Thecacineta Collin, 1909. In 1912, in a monograph on suctorian ciliates, Collin redescribed the genus and named T. calix as a type species. T. calix was investigated in detail by Matthes (1956), in his revision of thecacinetid suctorians. Several species found on the interstitial marine nematodes and harpacticoid copepods were synonymyzed with T. calix: T. desmodorae Schulz, T. subantarctica Allgen, T. donsi Allgen and T. paradesmodorae Allgen.

Jankowski (1981) proposed a new specific name, T. laophontis, for T. calix found by Matthes (1956) on copepod crustaceans. The basis for his conclusion was the presence of some morphological differences between forms from crustaceans and nematodes. However, Jankowski (1981) did not present any arguments to support his conclusions. We believe that the name proposed by Jankowski (1981) is a junior synonym of $T$. calix.

A species of Paracineta was identified by Moebius (1888), cited after Kahl, (1934) from the Kiel Bay of the North Sea from "Holocarus sp." under the name Acineta crenata (Fraipont 1878). According to Kahl's (1934) opinion, the identification of Par. crenata by Moebius (1888) was erroneous, and Kahl (1934) described it as a new species, Par. moebiusi.

Both Kahl (1934) and Curds (1987) have indicated the host name for Kahl's (1934) species as Holocarus sp. Kahl (1934) did not mention the systematic position of the host, whereas Curds (1987) noted that it was a crustacean. However, it is likely that this was a mistake, and that the host was a species of the mite genus Halacarus, family Halacaridae. We feel that Par. moebiusi is similar enough to T. calix to warrant making it a junior synonym of T. calix.

Distribution and host prevalence: T. calix was observed on halacarid mites by Gelmboldt \& Dovgal (2005). It has been found on the idiosoma and legs of Halacarellus sp. in Odessa gulf of the Black Sea near biological station of the Odessa National University in the interstitial at a depth of 5-20 cm.

Among the suctorians observed by Bartsch $(1989,1998)$ and Abé (1997), we identified T. calix from the Black Sea near Sevastopol on the idiosoma of Halacarellus micropectinatus Bartsch; the North Sea on Cop. fabricii (Lohmann) (Bartsch 1989, Fig. 19; Bartsch 1998, Fig. 90); and from the northwest Pacific Ocean off Hokkaido, Japan, on the posterodorsal plate of Actacarus octosetus Abé (Abé 1997, figs. 5G, F). As previously mentioned, T. calix has also been described from nematodes and copepods. Its presence on marine mites testifies to its wider distribution and host spectrum. 

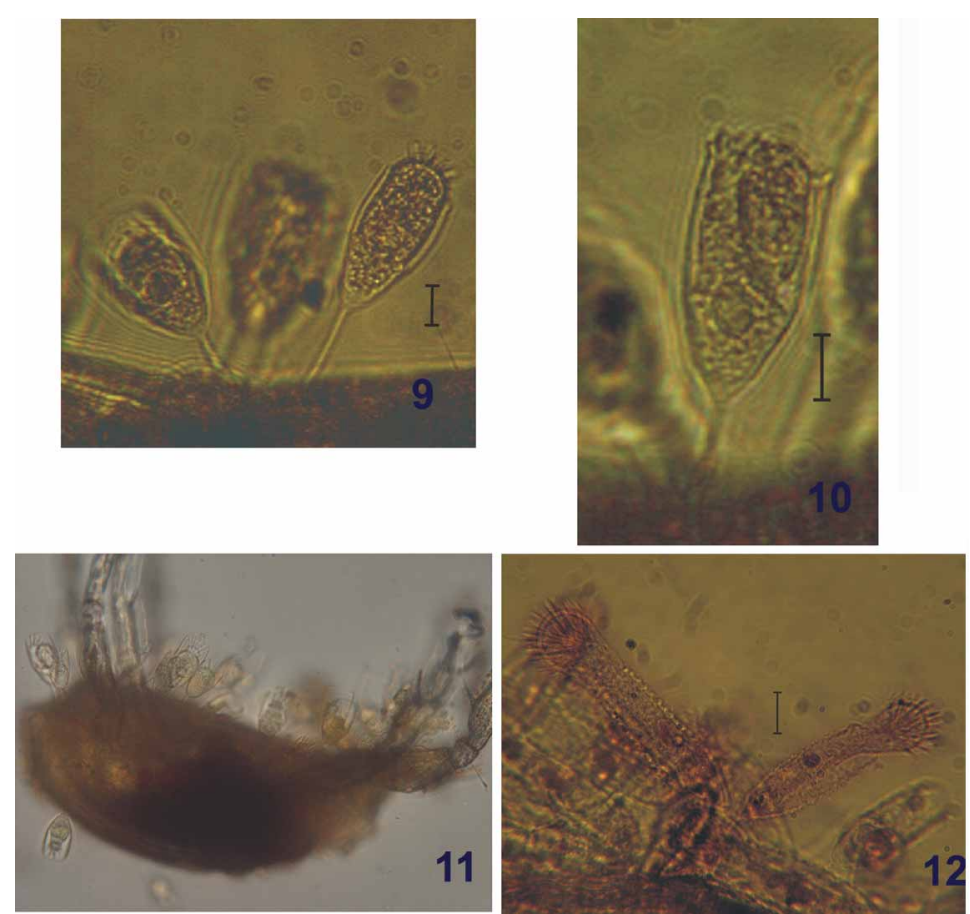

FIGURE 9. Praethecacineta halacari (Schulz 1933) (orig.). Scale bar $10 \mu \mathrm{m}$.

FIGURE 10. Budding of Praethecacineta halacari (Schulz 1933) (orig.). Scale bar $10 \mu \mathrm{m}$.

FIGURE 11. The settlement of Praethecacineta halacari on the halacarid mite from India (orig.)

FIGURE 12. Thecacineta calix (Schroder 1907) found in the Black Sea (orig.). Scale bar $20 \mu \mathrm{m}$.

\section{Thecacineta spp.}

Grimaldi (1965) reported Thecacineta sp. on Act. pygmaeus Schulz from Sardinia. Furthermore, the unidentified suctorian species observed (Bartsch 1994) on Halacarellus auzendei (Bartsch) from a deep sea (3500 m) Atlantic Ocean sample probably belonged to the genus Thecacineta. However, Bartsch's (1994) illustration was insufficient for species identification. It is possible that it represents a new suctorian species.

Figures of a suctorian in an SEM photomicrograph of Cop. laevisetosus Chatterjee, Lee \& Chang (Chatterjee et al. 2004) suggest that it is a species belonging to the genus Thecacineta.

\section{Subclass Endogenia Collin}

\section{Order Acinetida Raabe}

\section{Family Acinetidae Ehrenberg}

Acineta sulcata Dons, 1927, charact. emend

(Fig. 7-8)

= Acineta benesaepta Schulz

= Donsia sulcata (Dons)

= Plicophrya sulcata (Dons)

Diagnosis: Marine, commensal, suctorian ciliate, with stalk and lorica. Both lorica and cell body laterally compressed. Lorica heavily ridged transversely. With a wide flattened lorica base that is characteristic for the 
species. Apical aperture of the lorica dumb-bell shaped. Short, straight, stalk. Cell body shape varying from triangular to rectangular, attached to the aperture border of the lorica. Macronucleus ovoid, centrally located. Clavate tentacles arranged in two fascicles and placed at the two actinophores. Body dimensions: lorica length $16 \mu \mathrm{m}$ (35.2 $\mu \mathrm{m}$ after Schulz 1933), lorica width $13 \mu \mathrm{m}$ (26.4 $\mu \mathrm{m}$ after Schulz 1933), body length $13 \mu \mathrm{m}$ (33$55 \mu \mathrm{m}$ after Curds 1985), body width $11 \mu \mathrm{m}$, stalk length $14 \mu \mathrm{m}$ (22 $\mu \mathrm{m}$ after Schulz 1933). Macronucleus dimensions $8 \times 5 \mu \mathrm{m}$. Reproduction by endogenous monogemmic budding. The original measurements of Aci. sulcata were made using material collected in river Unava.

Acineta sulcata differs from Aci. tuberosa Ehrenberg, and other relatives, in that the lorica attaches to the apical aperture rather than at the bottom of the lorica, and by the wide flattened base of the lorica. However, the most characteristic difference is the presence of the pattern of transverse ridges (not folds as in some acinetids) on the lorica (Jankowski 2007).

Remarks on the systematics and nomenclature: The synonymy of Aci. benesaepta Schulz, 1933 with Aci. sulcata was established by Kahl (1934). In Curds' (1985) review, the genus, Plicophrya Jankowski was also synonymized with Acineta Ehrenberg. Mention of Aci. benesaepta as a valid name in Dovgal's (2002) work was an error.

Distribution and host prevalence: Aci. sulcata was found on halacarids from the northern Norwegian coast. Suctorian ciliates were later observed by Schulz (1933) on halacarid mites from Kiel Bay and named Aci. benesaepta. Precht (1935) later found Aci. benesaepta in Kiel Bay on a species of Copidognathus. Kahl (1934) also reported Aci. sulcata from seed shrimps. Jankowski $(1981,2007)$ noted numerous finds of this species on halacarid mites from the coast of Barents Sea.

Bartsch and Panesar (2000) recorded Acineta sp. on the idiosoma and legs of Cas. hyrcanus Viets from the Danube River near Vienna, Austria, and commented that this suctorian probably was Aci. tuberosa Ehrenberg. After observing the figures of that species (Bartsch \& Panesar 2000 Fig. 1), we believe that it probably is Aci. sulcata. The same species (Fig. 8) was also found by Dovgal on the legs of an unidentified freshwater halacarid mite from the Unava River (Fastov region, Kiev Province, Ukraine) (Dovgal \& Pesic 2007). In that paper, the mite host was indicated erroneously as an oribatid.

General remarks: Bartsch (2003) surveyed the interactions between halacarid mites and their symbionts, and pointed out that the first report of these ciliates from a halacarid mite, Thalassarachna hasten (Johnston), was mentioned in Gosse's (1855) paper. Subsequently, suctorians were regularly observed on psammobiont halacarids, often in high numbers (>60 ciliates per host).

Bartsch (2003) also stated that suctorians lived predominantly on halacarid adults and deutonymphs, and rarely on protonymphs and larvae because of short life span in protonymph and larva stages. Analysis of the literature and our own data have shown that only four suctorian species observed to date on halacarids, that can be identified with certainty are Lim. ceter, Pra. halacari, Thecacineta calix and Aci. sulcata. Two of these species, Pra. halacari and Aci. sulcata, are most likely specific on their halacarid hosts. The other two species, Lim. ceter and T. calix, can be found on different benthic invertebrate animals. All of the above mentioned ciliate species are found on marine or brackish water hosts. Acineta sulcata can also inhabit freshwater if their hosts are euryhaline.

Suctorian species from halacarids generally attach in the idiosomatic region, but are not restricted there. They also may occur on the gnathosoma and legs. Under conditions of high infestation levels, suctorians may occupy sites anywhere on the body of the host. 


\section{Acknowledgement}

The authors acknowledge the Indian Ocean-Census of Marine Life project for initial seed funding to facilitate the field work in Goa (India). Also, thanks are due to anonymous reviewers for their critical reading of the manuscript with useful comments.

\section{References}

Abé, H. (1997) Halacarid mites of the genus Actacarus (Acari: Halacaridae) from Hokkaido, Northern Japan. Species Diversity, 2, 31-42.

Bartsch, I. (1989) Copidognathus brifacius n. sp. (Halacaridae, Acari) und Bemerkungen zu weiteren Bewohners des Seeigels Spatangus purpureus (Echinoidea). Mitteilungen aus dem Hamburgischen zoologischen Museum Institut, $86,315-328$

Bartsch, I. (1994) Halacarid mites (Acari) from hydrothermal deep-sea sites. New records. Cahiers de Biologie Marine, $35,479-490$

Bartsch, I. (1998) Halacarinae (Acari: Halacaroidea) from the northwestern Black Sea: A review. Mitteilungen aus dem hamburgischen zoologischen Museum und Institut, 95, 143-178.

Bartsch, I. (2001) Black Sea Copidognathinae (Arachnida: Acari: Halacaridae): A review. Mitteilungen aus dem Museum für Naturkunde in Berlin, Zoologische Reiche, 77, 247-275.

Bartsch, I. (2003) A new arenicolous Copidognathus (Halacaridae: Acari) from Dampier, Western Australia. In: Wells, F.E., Walker, DL. \& Jones, D.S. (Eds.). The Marine Flora and Fauna of Dampier, Western Australia. Western Australian Museum, Perth. pp. 282-290.

Bartsch, I. \& Panesar, A.R. (2000) Die Meeresmilbe Caspihalacarus hyrcanus in der Donau bei wien, ein ponto-kaspisches Relikt. Natur und Museum, 130, 258-263.

Boshko, E.G. \& Dovgal, I.V. (2004) Sessile ciliates (Ciliophora). In: Karadag. Hydrobiological observations (Scientific works dedicated to $90^{\text {th }}$ anniversary of T. I. Vyazemsky Karadag Scientific Station and $25^{\text {th }}$ anniversary of Karadag Natural Reserve of Ukrainian National Academy of Sciences). Book 2. Simferopol: Sonat. pp. 313-316. (In Russian).

Chatterjee, T., De Troch, M. \& Chang, C.Y. (2006) Three Halacarid Mites of the Genus Copidognathus (Acari, Halacaridae) from Zanzibar, Tanzania. Cahiers de Biologie marine. 47, 177-187.

Chatterjee, T., Lee, J.M. \& Chang, C.Y. (2004) Two Copidognathus halacarids (Acari : Halacaridae) from Korea. The Korean Journal of Systematic Zoology, 20, 45-54.

Collin, B. (1909) Diagnoses preliminaires d'Acinetiens nouveaux ou mal connus. Comptes rendus hebdomadaires des séances de L'Académie des Sciences. Paris, 149, 1094-1095.

Collin, B. (1912) Etudes monographiques sur les Acinetiens. II.Morphologie, physiologie, systematique. Archives de Zoologie Expérimentale et Générale, 51, 1-457.

Curds, C.R. (1985) A revision of Suctoria (Ciliophora, Kinetofragminofora) 1.Acineta and its morphological relatives. Bulletin of the British Museum (Natural History), Zoology series, 48, 75-129.

Curds, C.R. (1987) A revision of Suctoria (Ciliophora, Kinetofragminofora) 5.The Paracineta and Corynophrya problem. A. R. Bulletin of the British Museum (Natural History), Zoology series, 52, 71-106.

Detcheva, R. (1992) Catalogi faunae Bulgaricae. 1. Protozoa, Ciliophora. In: Aedibus Academiae Scientiarum Bulgaricae. Sofia, $134 \mathrm{pp}$.

Dons, C. (1927) Neue und wenig bekannte Protozoen. Det Kongelige Norske Videnskabers Selskabs Skrifter, 7, pp. 1-17.

Dovgal, I.V. (1996) Keys for identification of tentaculous infusoria (Ciliophora,Suctoria) of the Ukrainian fauna. Vestnik Zoologii, Suppl., N2, 1-42. (In Russian).

Dovgal, I.V. (2002) Evolution, phylogeny and classification of Suctorea Claparède et Lachmann, 1858. Protistology, 2, 194-270.

Dovgal, I.V. \& Pesic, V. (2007) Acineta persiensis sp. n. (Ciliophora, Suctorea) - a new freshwater suctorian species from the water mites of genus Protzia (Acari, Hydrachnidia). Vestnik Zoologii, 41, 165-167.

Fraipont, J. (1878) Recherches sur les Acinetiens de la cote d'Ostende. Bulletin de l'Academie (r.) des sciences des lettres et des beaux arte de Belgique, 45, 247-299.

Gosse, P. (1855) Notes on some new and little-known marine animals. Annals and Magazine of Natural History, London, $16,306-313$.

Gelmboldt, M.V. \& Dovgal, I.V. (2005) The new finds of suctorian ciliates (Ciliophora, Suctorea) at the halacarid mites (Acari, Halacaridae) from the Ukrainian coast of the Black Sea. Vestnik Zoologii, Supplement N19, 85-86. (In Russian with English summary). 
Grimaldi, P. (1965) Osservazioni su alcuni elementi del mesopsammon della Sardegna. Monitore Zoologico Italiano, 73, 61-65.

Jankowski, A.V. (1981) New species, genera and families of tentacled infusoria (class Suctoria). Proceedings of the Zoologica lInstitute, 107, 80-115. (In Russian with English summary).

Jankowski, A.V. (2007) Review of taxa Phylum Ciliophora Doflein, 1901: In: Alimov A.F (Ed.): Protista: Handbook on Zoology. St. Petersburg: Nauka. Pt. 2, 415-993.

Kahl, A. (1934) Suctoria. In: Grimpe, G. \& Wagler, E (Eds.). Die Tierwelt der Nord- und Ostsee. Lief 26, 11, pp. 184226.

Matthes, D. (1956) Suktorienstudien VIII. Thecacineta calix (Schroder, 1907) (Thecacinetidae nov. fam.) und ihre Fortpflanzung durch Vermoid-Schwarmer. Archiv für Protistenkunde, 101, 477-528.

Matthes, D. \& Stiebler, G. (1970) Susswassersuktorien auf Arachniden. Archiv für Protistenkunde, 112, 65-70.

Matthes, D., Guhl, W. \& Haider, G. (1988) Suctoria und Urceolaridae. In: Protozoenfauna. Band 7/1. Stuttgart, etc.: Gustav Fisher Verlag. 309 pp.

Pepato, A.R. \& Tiago, C.G. (2005) New species and new occurences of Copidognathus (Acari, Halacaridae) from the northern littoral zone of Sao Paulo State (Brazil). Zootaxa, 1083, 1-35.

Precht, H. (1935) Epizoen der Kielr Bucht. Nova Acta Leopoldina Halle, N.F. 3, 405-474.

Schroder, O. (1907) Die Infusorien der deutschen sudpolar - Expedition. Ergebn. d. D. Sudpolar Expedition 1901-1903, 9, 349-360.

Schultz, E. (1933) Beitrage zur Kenntnis marinen Suctorien. V. Zoologischer Anzeiger, 103, 327-329.

Schultz, E. (1938) Beitrage zur Kenntnis marinen Suctorien. VIII. Kieler Meeresforschungen, 2, 354-355. 